\title{
Characteristics of Newly Isolated Xanthobacter Strains and Fatty Acid Compositions and Quinone Systems in Yellow-Pigmented Hydrogen-Oxidizing Bacteria
}

\author{
TEIZI URAKAMI, ${ }^{1 *}$ HISAYA ARAKI, ${ }^{2}$ AND KAZUO KOMAGATA ${ }^{3} \dagger$ \\ Biochemicals Division, Mitsubishi Gas Chemical Co., Marunouchi, Chiyoda-ku, Tokyo 100, 'Niigata Research Laboratory, \\ Mitsubishi Gas Chemical Co., Tayuhama, Niigata 950-31, ${ }^{2}$ and Institute of Molecular and Cellular Biosciences, \\ The University of Tokyo, Bunkyo-ku, Tokyo $113,{ }^{3}$ Japan
}

\begin{abstract}
Newly isolated Xanthobacter strains were characterized. In addition, the fatty acid compositions and quinone systems of gram-negative, yellow-pigmented, hydrogen-oxidizing bacteria belonging to the genera Xanthobacter, Hydrogenophaga, and Variovorax and related species were studied. Xanthobacter strains are nitrogen-fixing organisms that have a Q-10 ubiquinone system; the cellular fatty acids of these organisms include high levels of $\mathrm{C}_{18: 1}$ acid, and their hydroxy fatty acids include high levels of 3-OH $\mathrm{C}_{16: 0}$ acid. Hydrogenophaga strains are polarly flagellated organisms that have a Q-8 ubiquinone system. These bacteria can be divided into two groups on the basis of cellular fatty acid and hydroxy fatty acid compositions. Variovorax strains are peritrichously flagellated, non-nitrogen-fixing organisms that have a Q-8 ubiquinone system; the cellular fatty acids of these strains include high levels of $C_{16: 0}, C_{16: 1}$ and $C_{18: 1}$ acids, and their hydroxy fatty acids include 3-OH $C_{10: 0}$ and 2-OH $\mathrm{C}_{\text {14:0 }}$ acids. Xanthobacter, Hydrogenophaga, and Variovorax strains can be clearly distinguished from each other on the basis of their quinone systems and cellular fatty acid compositions.
\end{abstract}

Previously (28-31), we described a group of gram-negative methanol-utilizing bacteria on the basis of their morphological characteristics, utilization of carbon compounds, DNA base compositions, DNA-DNA hybridization data, cellular fatty acid compositions, ubiquinone systems, and enzyme electrophoretic properties. The group 5 bacteria that we described $(29,30)$ are nitrogen-fixing, hydrogen-oxidizing, non-sporeforming, gram-negative, rod-shaped, yellow-pigmented organisms that have a Q-10 ubiquinone system and cellular fatty acids that include high levels of $\mathrm{C}_{18: 1}$. Xanthobacter strains (22, 35,38 ) are included in this group.

Corynebacterium autotrophicum (6) and "Mycobacterium flavum" (= "Microbacterium flavum") $(14,23)$ were transferred to the new genus Xanthobacter as Xanthobacter autotrophicus and Xanthobacter flavus by Wiegel et al. (38) and Malik and Claus (22), respectively. In 1987, Xanthobacter agilis (18) was described as a third Xanthobacter species, and this species could be clearly distinguished from the two other Xanthobacter species on the basis of pleomorphism, motility, and colony color (2). X. autotrophicus DSM $432^{\mathrm{T}}(\mathrm{T}=$ type strain), DSM 431, DSM 685, DSM 1393 (= JCM 7861), DSM 1618 (= JCM 7862), DSM 2009 (= JCM 7863), and DSM 597 (= JCM 7864), $X$. flavus NCIB $1007^{\mathrm{T}}$ (= DSM $338^{\mathrm{T}}$ ), and all of our isolates (strains BY-1, BY-3 to BY-11, and BY-15) were gram-negative, non-spore-forming, rod-shaped, methanol-utilizing organisms whose cells were 0.5 to 0.9 by 1.0 to $3.0 \mu \mathrm{m}$ and had rounded ends. Nonmucoid yellow colonies were produced on PYG medium, nutrient medium, or methanol-containing me-

TABLE 1. Quinone compositions of yellow colony-forming bacteria

\begin{tabular}{|c|c|c|c|c|c|c|c|c|c|c|c|c|c|c|}
\hline \multirow{4}{*}{ Strain } & \multicolumn{14}{|c|}{$\%$ of total quinones } \\
\hline & \multicolumn{4}{|c|}{ Ubiquinone homologs } & \multicolumn{10}{|c|}{ Menaquinone homologs } \\
\hline & \multirow{2}{*}{ Q-7 } & \multirow{2}{*}{ Q-8 } & \multirow{2}{*}{ Q-9 } & \multirow{2}{*}{ Q-10 } & \multicolumn{2}{|c|}{ MK-6 } & \multicolumn{2}{|c|}{ MK-7 } & \multicolumn{2}{|c|}{ MK-8 } & \multicolumn{2}{|c|}{ MK-9 } & \multicolumn{2}{|c|}{ MK-10 } \\
\hline & & & & & $\mathrm{H}_{0}$ & $\mathrm{H}_{2}$ & $\mathbf{H}_{0}$ & $\mathrm{H}_{2}$ & $\mathrm{H}_{0}$ & $\mathrm{H}_{2}$ & $\mathrm{H}_{0}$ & $\mathrm{H}_{2}$ & $\mathbf{H}_{0}$ & $\mathrm{H}_{2}$ \\
\hline Conynebacterium flavescens NCIB $8707^{\mathrm{T}}$ & & & & & 1.6 & 0.9 & 9.3 & 11.3 & 14.7 & 58.4 & 0.4 & 3.5 & & \\
\hline $\begin{array}{l}\text { "Mycobacterium flavum subsp. methanicum" } \\
\text { NCIB } 9738\end{array}$ & & & & & & & 1.0 & 0.2 & 2.3 & 9.8 & 0.3 & 86.4 & & 0.1 \\
\hline $\begin{array}{l}\text { "Mycobacterium flavum subsp. methanicum" } \\
\text { NCIB } 9742\end{array}$ & & & & & & & 0.8 & & 2.3 & 10.4 & & 86.5 & & \\
\hline Hydrogenophaga flava DSM $619^{\mathrm{T}}$ & 0.3 & 84.2 & 15.4 & 0.1 & & & & & & & & & & \\
\hline Hydrogenophaga pseudoflava DSM $1034^{\mathrm{T}}$ & 1.3 & 94.2 & 4.5 & & & & & & & & & & & \\
\hline Hydrogenophaga palleronii DSM $63^{\mathrm{T}}$ & 1.4 & 96.6 & 1.9 & 0.1 & & & & & & & & & & \\
\hline Variovorax paradoxus DSM $30034^{\mathrm{T}}$ & 0.9 & 97.9 & 1.2 & & & & & & & & & & & \\
\hline
\end{tabular}

* Corresponding author. Mailing address: Biochemicals Division, Mitsubishi Gas Chemical Co., Mitsubishi Building, Marunouchi, Chiyoda-ku, Tokyo 100, Japan. Phone: (03) 3283-4833. Fax: (03) 32835184 .

$\dagger$ Present address: Department of Agricultural Chemistry, Tokyo University of Agriculture, Sakuragaoka 1-1-1, Setagaya-ku, Tokyo 156, Japan. 
TABLE 2. Cellular fatty acid compositions of yellow colony-forming bacteria

\begin{tabular}{|c|c|c|c|c|c|c|c|c|c|c|c|c|c|c|c|c|}
\hline \multirow{3}{*}{ Strain } & \multicolumn{16}{|c|}{$\%$ of: } \\
\hline & \multicolumn{8}{|c|}{ Straight-chain acids } & \multicolumn{2}{|c|}{$\begin{array}{l}\text { Cyclo- } \\
\text { propane } \\
\text { acids }\end{array}$} & \multicolumn{2}{|c|}{$\begin{array}{l}\text { 10-Methyl } \\
\text { acids }\end{array}$} & \multicolumn{3}{|c|}{$\begin{array}{l}\text { 3-Hydroxy } \\
\text { acids }\end{array}$} & \multirow{2}{*}{$\begin{array}{l}2-\mathrm{OH} \\
\mathrm{C}_{14: 0}\end{array}$} \\
\hline & $\mathrm{C}_{14: 0}$ & $C_{15: 0}$ & $C_{16: 0}$ & $\mathrm{C}_{16: 1}$ & $\mathrm{C}_{17: 0}$ & $\mathrm{C}_{18: 0}$ & $\mathrm{C}_{18: 1}$ & $\mathrm{C}_{19: 0}$ & $C_{17: 0}$ & $\mathrm{C}_{19: 0}$ & $t-C_{17: 0}$ & $\mathrm{t}-\mathrm{C}_{19: 0}$ & $\begin{array}{l}3-\mathrm{OH} \\
\mathrm{C}_{1000}\end{array}$ & $\begin{array}{l}3-\mathrm{OH} \\
\mathrm{C}_{15: 0}\end{array}$ & $\begin{array}{l}3-\mathrm{OH} \\
\mathrm{C}_{16: 0}\end{array}$ & \\
\hline Corynebacterium flavescens NCIB $8707^{\mathrm{T}}$ & & & 9.0 & 0.9 & & 7.4 & 74.4 & & & & 0.3 & 8.0 & & & & \\
\hline $\begin{array}{l}\text { "Mycobacterium flavum subsp. methanicum" } \\
\text { NCIB } 9738\end{array}$ & 0.1 & 7.2 & 25.5 & 6.7 & 0.7 & 4.5 & 45.3 & 0.2 & 0.5 & 2.8 & 2.9 & 3.6 & & & & \\
\hline $\begin{array}{l}\text { "Mycobacterium flavum subsp. methanicum" } \\
\text { NCIB } 9742\end{array}$ & 0.1 & 8.1 & 26.7 & 7.7 & 0.7 & 6.0 & 42.0 & 0.2 & & 3.5 & 1.9 & 3.1 & & & & \\
\hline Hydrogenophaga flava DSM $619^{\mathrm{T}}$ & 3.3 & 0.8 & 32.4 & 56.6 & 0.3 & 0.3 & 2.8 & & 0.5 & & & & 3.0 & & & \\
\hline Hydrogenophaga pseudoflava DSM $1034^{\mathrm{T}}$ & 2.2 & 0.5 & 32.2 & 52.7 & 0.4 & 0.4 & 10.4 & & 0.3 & & & & 1.2 & & & \\
\hline Hydrogenophaga palleronii DSM $63^{\mathrm{T}}$ & 0.2 & 0.1 & 31.5 & 45.2 & 1.0 & 0.2 & 21.4 & & & & & & & 0.1 & 0.2 & \\
\hline Variovorax paradoxus DSM $30034^{\mathrm{T}}$ & 0.3 & 0.9 & 33.9 & 34.3 & 1.1 & 0.4 & 17.2 & & 3.9 & & & & 2.1 & & & 5.3 \\
\hline
\end{tabular}

dia. The cells occurred singly or rarely in pairs and were nonmotile. The organisms grew abundantly in nutrient broth and PYG broth. No water-soluble fluorescent pigment was produced on King B medium. Granules of poly- $\beta$-hydroxybutyric acid accumulated in the cells. The methyl red and the VogesProskauer tests in glucose phosphate broth were negative. Indole and hydrogen sulfide were not produced. Hydrolysis of gelatin and starch was not observed. Ammonia was produced. Denitrification was negative. Litmus milk was not changed. All of the strains utilized glycerol, succinic acid, citric acid, acetic acid, propionic acid, ethanol, $N, N$-dimethylformamide, and hydrogen, but did not grow at the expense of L-arabinose, galactose, maltose, lactose, trehalose, D-glucitol, D-mannitol, inositol, soluble starch, cellobiose, L-histidine, L-phenylalanine, tetramethylammonium hydroxide, or methane. All strains except $X$. autotrophicus DSM 431 utilized methanol; all strains except $X$. autotrophicus DSM 431 and DSM 597 utilized Dglucose; and all strains except $X$. autotrophicus DSM 431, DSM 1618, and DSM 2009 utilized malonic acid. Utilization of Dxylose, D-mannose, D-fructose, sucrose, D-ribose, monomethylamine, dimethylamine, and trimethylamine varied among the strains. None of the strains produced acid oxidatively from L-arabinose, D-xylose, D-glucose, D-mannose, galactose, maltose, lactose, trehalose, D-glucitol, D-mannitol, inositol, glycerol, and soluble starch. $X$. autotrophicus DSM 432 ${ }^{\mathrm{T}}$, DSM 431, and DSM 685 produced acid weakly from D-fructose, and $X$. autotrophicus DSM 1393, DSM 1618, and DSM 2009 produced acid weakly from D-fructose and sucrose. However, other strains did not produce acid from $D$-fructose and sucrose. Acids were not produced fermentatively. Xanthobacter strains and our isolates did not require amino acids for growth. The requirement for vitamins varied among strains. $X$. autotrophicus DSM 432 ${ }^{\mathrm{T}}$, DSM 431, DSM 685, DSM 1393, DSM 1618, and DSM 2009 did not require vitamins for growth, but $X$. flavus NCIB $10071^{\mathrm{T}}, X$. autotrophicus DSM 597, and all of our isolates had an absolute requirement for biotin. On the basis of these physiological characteristics, all of our isolates were identified as $X$. flavus strains, and strain DSM 597 was reidentified as a member of $X$. flavus.

The yellow-pigmented bacteria Corynebacterium flavescens (= Microbacterium flavum") $(5,8,14)$ and "Mycobacterium flavum subsp. methanicum" (20) were confused with $X$. flavus (= "Mycrobacterium flavum" $301^{\mathrm{T}}\left[=\right.$ NCIB $\left.1007^{\mathrm{T}}\right]$ ) until $X$. flavus and $C$. flavescens were described by Malik and Claus (22) and Barksdale et al. (5), respectively. C. flavescens (5) and "Mycobacterium flavum subsp. methanicum" strains are grampositive bacteria and do not utilize hydrogen, methanol, monomethylamine, dimethylamine, trimethylamine, tetramethylammonium hydroxide, and $N, N$-dimethylformamide. Furthermore, these organisms have different menaquinone systems, as shown in Table 1. C. flavescens contains mycolic acid and a high level of $C_{18: 1}$ acid, whereas "Mycobacterium flavum subsp. methanicum" strains contain mycolic acid, a high level of $\mathrm{C}_{18: 1}$ acid, and a relatively high level of $\mathrm{C}_{16: 0}$ acid, as shown in Tables 2 and 3. Hydroxy fatty acids have not been detected in these strains.

The yellow-pigmented hydrogen-oxidizing bacteria (2) Pseudomonas flava, Pseudomonas pseudoflava, Pseudomonas palleronii, and Pseudomonas taeniospiralis were placed in the new genus Hydrogenophaga as Hydrogenophaga flava, Hydro-

TABLE 3. Hydroxy fatty acid compositions presence and carotenoid pigments of yellow colony-forming bacteria and the presence of mycolic acids in these bacteria

\begin{tabular}{|c|c|c|c|c|c|c|}
\hline \multirow{2}{*}{ Strain } & \multicolumn{3}{|c|}{$\begin{array}{l}\text { 3-Hydroxy acid } \\
\text { composition }(\%)\end{array}$} & \multirow{2}{*}{$\begin{array}{c}\text { 2-Hydroxy acid } \\
\text { composition } \\
\left(\% \text { of } 2-\mathrm{OH} \mathrm{C} \mathrm{C}_{14: 0}\right)\end{array}$} & \multirow{2}{*}{$\begin{array}{l}\text { Presence of } \\
\text { mycolic acids }\end{array}$} & \multirow{2}{*}{$\begin{array}{l}\text { Carotenoid pigment } \\
\text { absorption } \\
\text { maximum }(\mathrm{nm})\end{array}$} \\
\hline & $\begin{array}{c}3-\mathrm{OH} \\
\mathrm{C}_{10: 0}\end{array}$ & $\begin{array}{l}3-\mathrm{OH} \\
\mathrm{C}_{15: 0}\end{array}$ & $\begin{array}{l}3-\mathrm{OH} \\
\mathrm{C}_{16: 0}\end{array}$ & & & \\
\hline Corynebacterium flavescens NCIB $8707^{\mathrm{T}}$ & & & & & + & 450 \\
\hline "Mycobacterium flavum subsp. methanicum" NCIB 9738 & & & & & + & 450 \\
\hline "Mycobacterium flavum subsp. methanicum" NCIB 9742 & & & & & + & 450 \\
\hline Hydrogenophaga flava DSM $619^{\mathrm{T}}$ & 100 & & & & - & 450 \\
\hline Hydrogenophaga pseudoflava DSM $1034^{\mathrm{T}}$ & 100 & & & & - & 450 \\
\hline Hydrogenophaga palleronii DSM $63^{\mathrm{T}}$ & & 20.7 & 79.3 & & - & 450 \\
\hline Variovorax paradoxus DSM $30034^{\mathrm{T}}$ & 100 & & & 100 & - & 420 \\
\hline
\end{tabular}


genophaga pseudoflava, Hydrogenophaga palleronii, and Hydrogenophaga taeniospiralis, respectively, by Willems et al. in 1989 (39). Willems et al. (40) later described another new genus, the genus Variovorax, for Alcaligenes paradoxus, which became Variovorax paradoxus. These bacteria oxidize hydrogen, but do not utilize methanol, monomethylamine, dimethylamine, trimethylamine, tetramethylammonium hydroxide, and $N, N$-dimethylformamide. These species have a Q-8 ubiquinone system, as shown in Table 1. Biswas and Thiele (7) reported that $H$. pseudoflava contains Q-8 and Q-10 systems, but this information was corrected in this study (Table 1). Hydrogenophaga species can be divided into two groups on the basis of cellular fatty acid composition and hydroxy fatty acid composition. $H$. flava and $H$. pseudoflava strains contain high levels of $\mathrm{C}_{16: 0}$ acids and high levels of 3-OH $\mathrm{C}_{10: 0}$ acid, whereas $H$. palleronii contains high levels of $\mathrm{C}_{16: 0}$ and $\mathrm{C}_{16: 1}$ acids, a high level of 3-OH C $\mathrm{C}_{10: 0}$ acid, and a relatively high level of 3-OH $\mathrm{C}_{15: 0}$ acid, as shown in Tables 2 and 3. $V$. paradoxus contains high levels of $\mathrm{C}_{16: 0}, \mathrm{C}_{16: 1}$, and $\mathrm{C}_{18: 1}$ acids, as well as high levels of 3-OH $\mathrm{C}_{10: 0}$ and 2-OH C $14: 0$ acids. Our results differ from those of Willems et al. (39) in the proportions of $C_{16: 0}, C_{16: 1}$, and $C_{18: 1}$ acids. The reason for this is not clear.

The absorption maximum of the pigments produced by $V$. paradoxus was approximately $420 \mathrm{~nm}$, while all other species, including C. flavescens, "Mycobacterium flavum subsp. methanicum," and Hydrogenophaga species produced zeaxanthin dirhamnoside pigments (15), which had an absorption maximum at $450 \mathrm{~nm}$ (Table 1).

The Gram reactions of Xanthobacter species were described as gram positive or gram variable in Bergey's Manual of Systematic bacteriology (37). However, Xanthobacter strains are gram-negative bacteria as determined by the ultrastructure of the cell wall $(16,33,37)$, the presence of lipopolysaccharide $(36,37)$, the cellular fatty acid composition $(30)$, and the quinone system (29). For a long time it was thought that Xanthobacter strains are nonmotile bacteria, but in 1992 Reding et al. (24) reported that $X$. flavus is a motile species. The motility of $X$. flavus was observed when cultures were grown with methanol, ethanol, $n$-propanol, isopropanol, butanol, or gluconate as a carbon source; furthermore, motility of up to $50 \%$ of the cells of a slime-reduced mutant of $X$. autotrophicus DSM $432^{\mathrm{T}}$ was observed under special cultural conditions. The characteristics of the hydrogen-oxidizing yellow-pigmented bacteria (Xanthobacter, Hydrogenophaga, and V. paradoxus strains) and related bacteria ( $C$. flavescens and "Mycobacterium flavum subsp. methanicum") are summarized in Table 4. Xanthobacter strains can be distinguished from Hydrogenophaga strains, $V$. paradoxus, and two related species on the basis of their morphological characteristics $(21,37,39)$, nitrogen fixation characteristics, utilization of methanol, ubiquinone systems, cellular fatty acid compositions, and hydroxy fatty acid compositions. Hydrogenophaga strains can be divided into two subgroups (the $H$. flava-H. pseudoflava subgroup and the $H$. palleronii subgroup) on the basis of their cellular fatty acid compositions, hydroxy fatty acid compositions, and DNA-DNA hybridization data (3). These results are supported by rRNA-DNA hybridization data (39). We believe that the genus Hydrogenophaga should be characterized more precisely in the future. $V$. paradoxus resembles members of the genus Hydrogenophaga in morphological characteristics and oxidization of hydrogen, but $V$. paradoxus differs in the kind of carotenoid pigment that it forms, its cellular fatty acid composition, and its hydroxy fatty acid composition. The chemotaxonomic characteristics determined in this study support the creation of the new genus Variovorax for $A$. paradoxus proposed by Willems et al. (40).

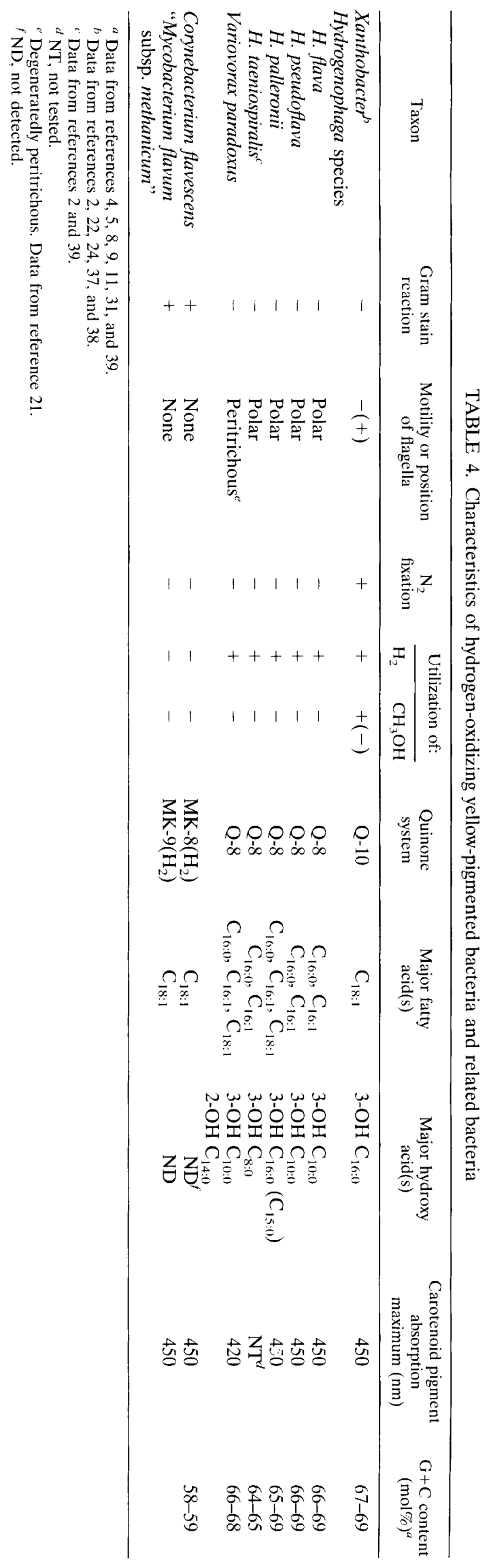




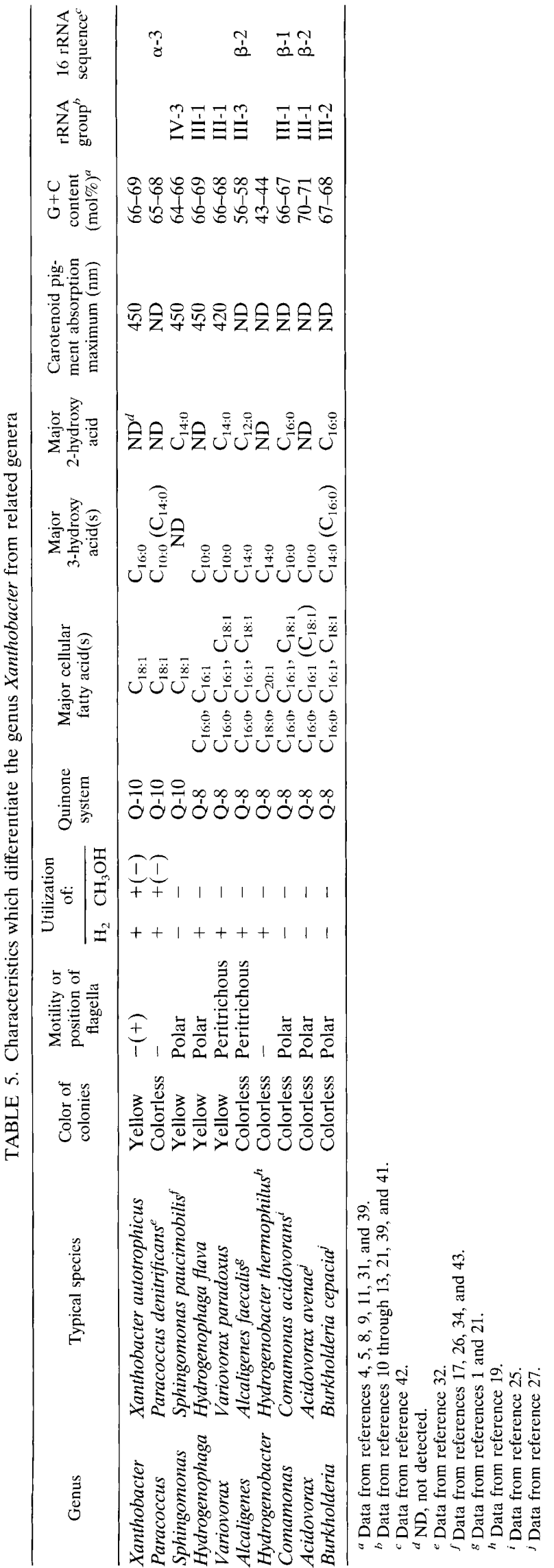

Minimal characteristics for differentiating the genus Xanthobacter from related genera are shown in Table 5.

\section{REFERENCES}

1. Akagawa, M., and K. Yamasato. 1989. Synonymy of Alcaligenes aquamarinus, Alcaligenes faecalis subsp. homari, and Deleya aesta: Deleya aquamarina comb. nov, as the type species of the genus Deleya. Int. J. Syst. Bacteriol. 39:462-466.

2. Aragno, M., and H. G. Schlegel. 1991. The mesophilic, hydrogen-oxidizing (knallgas) bacteria, p. 344-384. In A. Balows, H. G. Truper, M. Dworkin, W. Harder, and K. H. Schleifer (ed.), The prokaryotes. A handbook on biology of bacteria, 2nd ed., vol. 1. Springer Verlag, New York.

3. Auling, G., M. Dittbrenner, M. Maarzahl, T. Nokhal, and M. Reh. 1980. Deoxyribonucleic acid relationships among hydrogen-oxidizing strains of the genera Pseudomonas, Alcaligenes, and Paracoccus. Int. J. Syst. Bacteriol. 30:123-128.

4. Auling, G., M. Reh, C. M. Lee, and H. G. Schlegel. 1978. Pseudomonas pseudoflava, a new species of hydrogen-oxidizing bacteria: its differentiation from Pseudomonas flava and other yellow-pigmented, gram-negative, hydrogen-oxidizing species. Int. J. Syst. Bacteriol. 28:82-95.

5. Barksdale, L., M.-A. Laneelle, M. C. Pollice, J. Asselineau, M. Welby, and M. W. Norgard. 1979. Biological and chemical basis for the reclassification of Microbacterium flavum Orla-Jensen as Connebacterium flavescens nom. nov. Int. J. Syst. Bacteriol. 29:222-233.

6. Baumgarten, J., M. Reh, and H. G. Schlegel. 1974. Taxonomic studies on some gram-positive coryneform hydrogen bacteria. Arch. Microbiol. 100: 207-217.

7. Biswas, C. J., and O. W. Thiele. 1983. Ubiquinones (coenzyme Q) in hydrogen oxidizing bacteria. Syst. Appl. Microbiol. 4:181-183.

8. Collins-Thompson, D. L., T. Sorhaug, L. D. Witter, and Z. J. Ordal. 1972. Taxonomic consideration of Microbacterium lacticum, Microbacterium flavum, and Microbacterium thermosphactum. Int. J. Syst. Bacteril. 22:65-72.

9. Davis, D. H., R. Y. Stainer, and M. Doudoroff. 1970. Taxonomic studies on some gram negative polarly flagellated "hydrogen bacteria" and related species. Arch. Mikrobiol. 70:1-13.

10. De Ley, J., P. Segers, K. Kersters, W. Mannheim, and A. Lievens. 1986. Intra- and intergeneric similarities of the Bordetella ribosomal ribonucleic acid cistrons: proposal for a new family, Alcaligenaceae. Int. J. Syst. Bacteriol. 36:405-414.

11. De Vos, P., and J. De Ley. 1983. Intra- and intergeneric similarities of Pseudomonas and Xanthomonas ribosomal ribonucleic acid cistrons. Int. J. Syst. Bacteriol. 33:487-509.

12. De Vos, P., K. Kersters, E. Falsen, B. Pot, M. Gillis, P. Segers, and J. De Ley. 1985. Comamonas Davis and Park 1962 gen. nov., nom. rev. emend., and Comamonas terrigena Hugh 1962 sp. nov., nom. rev. Int. J. Syst. Bacteriol. 35:443-453.

13. De Vos, P., A. Van Landschoot, P. Segers, R. Tytgat, M. Gillis, M. Bauwens, R. Rossau, M. Goor, B. Pot, K. Kersters, P. Lizzaraga, and J. De Ley. 1989. Genotypic relationships and taxonomic localization of unclassified Pseudomonas and Pseudomonas-like strains by deoxyribonucleic acid-ribosomal ribonucleic acid hybridizations. Int. J. Syst. Bacteriol. 39:35-49.

14. Doetsch, R. N., and M. J. Pelczar, Jr. 1948. The microbacteria. I. Morphological and physiological characteristics. J. Bacteriol. 56:37-49.

15. Hertzberg, S., G. Borch, and S. Liaaen-Jensen. 1976. Bacterial carotenoids. L. Absolute configuration of zeaxanthin dirhamnoside. Arch. Microbiol. 110:95-99.

16. Hollander, R., and G. Vobis. 1979. The association of Mycobacterium flavum 301 with gram-negative bacteria: ultrastructural and biochemical evidence. Antonie van Leeuwenhoek J. Microbiol. Serol, 45:605-611.

17. Holmes, B., R. J. Owen, A. Evans, H. Malnick, and W. R. Willcox. 1977. Pseudomonas paucimobilis, a new species isolated from human clinical specimens, the hospital environment, and other sources. Int. J. Syst. Bacteriol. 27:133-146.

18. Jenni, B., and M. Aragno. 1987. Xanthobacter agilis sp. nov., a motile, dinitrogen-fixing, hydrogen-oxidizing bacterium. Syst. Appl. Microbiol. 9:254257.

19. Kawasumi, T., Y. Igarashi, T. Kodama, and Y. Minoda. 1984. Hydrogenobacter thermophilus gen. nov., an extremely thermophilic, aerobic, hydrogenoxidizing bacterium. Int. J. Syst. Bacteriol. 34:5-10.

20. Kersten, D. K. 1964. Behavior of hydrocarbon-oxidizing mycobacteria toward various carbon sources. Mikrobiologiya 33:31-37.

21. Kersters, K., and J. De Ley. 1984. Genus Alcaligenes Castellani and Chalmers $1919,936^{\mathrm{AL}}$, p. 361-373. In N. R. Krieg and J. G. Holt (ed.), Bergey's manual of systematic bacteriology, vol. 1. The Williams \& Wilkins Co., Baltimore.

22. Malik, K. A., and D. Claus. 1979. Xanthobacter flavus, a new species of nitrogen-fixing hydrogen bacteria. Int. J. Syst. Bacteriol. 29:283-287.

23. Orla-Jensen, S. 1919. The lactic acid bacteria. Host, Copenhagen.

24. Reding, H. K., G. L. M. Croes, L. Dijkhuizen, and J. Wiegel. 1992. Emendation of Xanthobacter flavus as a motile species. Int. J. Syst. Bacteriol. 42:309-311. 
25. Tamaoka, J., D. Ha, and K. Komagata. 1987. Reclassification of Pseudomonas acidovorans den Dooren de Jong 1926 and Pseudomonas testosteroni Marcus and Talalay 1959 as Comamonas acidovorans comb. nov. and Comamonas testosteroni comb. nov., with an emended description of the genus Comamonas. Int. J. Syst. Bacteriol. 37:52-59.

26. Urakami, T., H. Araki, H. Oyanagi, K. Suzuki, and K. Komagata. 1992 Transfer of Pseudomonas aminovorans (den Dooren de Jong 1926) to Aminobacter gen. nov. as Aminobacter aganoensis sp. nov. and Aminobacter niigataensis sp. nov. Int. J. Syst. Bacteriol. 42:84-92.

27. Urakami, T., C. Ito-Yoshida, H. Araki, T. Kijima, K. Suzuki, and K. Komagata. 1994. Transfer of Pseudomonas plantarii and Pseudomonas glumae to Burkholderia as Burkholderia spp. and description of Burkholderia vandii sp. nov. Int. J. Syst. Bacteriol. 44:235-245.

28. Urakami, T., and K. Komagata. 1981. Electrophoretic comparison of enzymes in gram negative methanol-utilizing bacteria. J. Gen. Appl. Microbiol. 27:381-403.

29. Urakami, T., and K. Komagata. 1986. Occurrence of isoprenoid compounds in gram-negative methanol-, methane-, and methylamine-utilizing bacteria. J. Gen. Appl. Microbiol. 32:317-341.

30. Urakami, T., and K. Komagata. 1987. Cellular fatty acid composition with special reference to the existence of hydroxy fatty acids in gram-negative methanol-, methane-, and methylamine-utilizing bacteria. J. Gen. Appl. Microbiol. 33:135-165.

31. Urakami, T., J. Tamaoka, and K. Komagata. 1985. DNA base composition and DNA-DNA homologies of methanol-utilizing bacteria. J. Gen. Appl. Microbiol. 31:243-253.

32. Urakami, T., J. Tamaoka, K. Suzuki, and K. Komagata. 1989. Paracoccus alcaliphilus sp. nov., an alkaliphilic and facultatively methylotrophic bacterium. Int. J. Syst. Bacteriol. 39:116-121.

33. Walther-Mauruschat, A., M. Aragno, F. Mayer, and H. G. Schlegel. 1977. Micromorphology of gram-negative hydrogen bacteria. II. Cell envelope, membranes, and cytoplasmic inclusions. Arch. Microbiol. 114:101-110.

34. Weeks, O. B. 1974. Genus Flavobacterium Bergey et al. 1923,97, p. 357-364. In R. E. Buchanan and N. E. Gibbons (ed.), Bergey's manual of determinative bacteriology, 8th ed. The Williams \& Wilkins Co., Baltimore.

35. Wiegel, J. 1991. The genus Xanthobacter, p. 2365-2383. In A. Balows, H. G. Truper, M. Dworkin, W. Harder, and K. H. Scheifer (ed.), The prokaryotes.
A handbook on biology of bacteria, 2nd ed., vol. 3. Springer Verlag, New York.

36. Wiegel, J., and F. Mayer. 1978. Isolation of lipopolysaccharides and the effect of polymyxin B on the outer membrane of Corynebacterium autotrophicum. Arch. Microbiol. 118:67-69.

37. Wiegel, J., and H. S. Schlegel. 1984. Genus Xanthobacter Wiegel, Wilke, Baumgarten, Opitz and Schlegel 1978,573 AL p. 325-333. In N. R. Krieg and J. G. Holt (ed.), Bergey's manual of systematic bacteriology, vol. 1. The Williams \& Wilkins Co., Baltimore.

38. Wiegel, J., D. Wilke, J. Baumgarten, R. Opitz, and H. S. Schlegel. 1978. Transfer of the nitrogen-fixing hydrogen bacterium Corynebacterium autotrophicum Baumgarten et al. to Xanthobacter gen. nov. Int. J. Syst. Bacteriol. 28:573-581.

39. Willems, A., J. Busse, M. Goor, B. Pot, E. Falsen, E. Jantzen, B. Hoste, M. Gillis, K. Kersters, G. Auling, and J. De Ley. 1989. Hydrogenophaga, a new genus of hydrogen-oxidizing bacteria that includes Hydrogenophaga flava comb. nov. (formerly Pseudomonas flava), Hydrogenophaga palleronii (formerly Pseudomonas palleronii), Hydrogenophaga pseudoflava (formerly Pseudomonas pseudoflava and "Pseudomonas carboxydoflava"), and Hydrogenophaga taeniospiralis (formerly Pseudomonas taeniospiralis). Int. J. Syst. Bacteriol. 39:319-333.

40. Willems, A., J. De Ley, M. Gillis, and K. Kersters. 1991. Comamonadaceae, a new family encompassing the acidovorans rRNA complex, including Variovorax paradoxus gen. nov., comb. nov., for Alcaligenes paradoxus (Davis 1969). Int. J. Syst. Bacteriol. 41:445-450.

41. Willems, A., M. Goor, S. Thielemans, M. Gillis, K. Kersters, and J. De Ley. 1992. Transfer of several phytopathogenic Pseudomonas species to Acidovorax as Acidovorax avenae subsp. avenae subsp. nov., comb. nov., Acidovorax avenae subsp. citrulli, Acidovorax avenae subsp. cattleyae, and Acidovorax konjaci. Int. J. Syst. Bacteriol. 42:107-119.

42. Woese, C. 1987. Bacterial evolution. Microbiol. Rev. 51:221-271.

43. Yabuuchi, E., I. Yano, H. Oyaizu, Y. Hashimoto, T. Ezaki, and H. Yamamoto. 1990. Proposals of Sphingomonas paucimobilis gen. nov. and comb. nov., Sphingomonas parapaucimobilis sp. nov., Sphingomonas yanoikuyae sp. nov., Sphingomonas adhaesiva sp. nov., Sphingomonas capsulata comb. nov., and two genospecies of the genus Sphingomonas. Microbiol. Immunol. 34:99-119. 